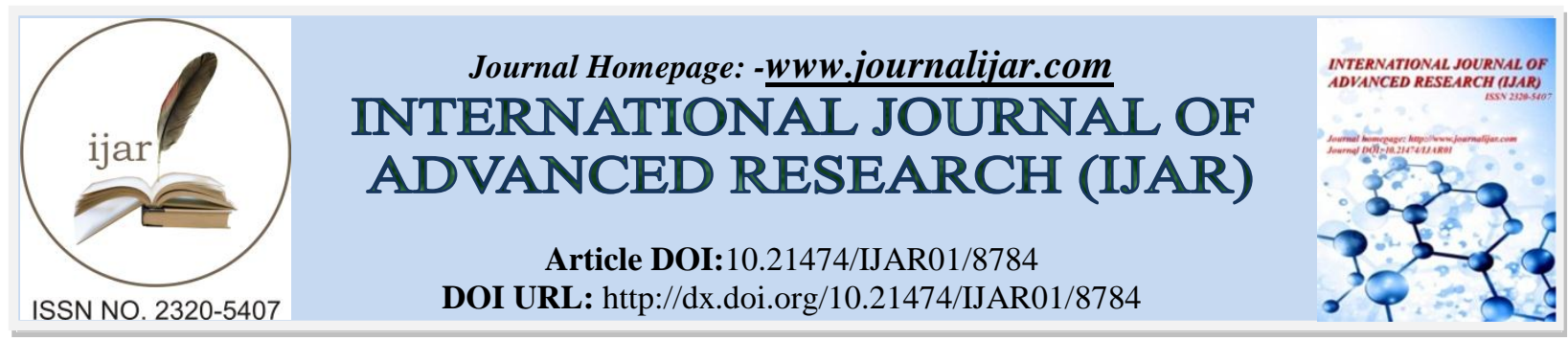

RESEARCH ARTICLE

\title{
EFFECT OF REPLACEMENT OF FISHMEAL WITH SOME CHEAP ANIMAL PROTEIN SOURCES ON THE GROWTH PERFORMANCE OF JUVENILES OF LABEO ROHITA.
}

\author{
Roopma Gandotra, Ritu Kumari and Dalbir Singh Parihar.
} Department of Zoology, University of Jammu, Jammu, 180006.

\section{Manuscript Info}

\section{Manuscript History}

Received: 02 February 2019

Final Accepted: 04 March 2019

Published: April 2019

\section{Key words:-}

Animal protein, Fishmeal, Silkworm pupae, Slaughter house waste, Labeo rohita.

\begin{abstract}
During the present investigation, various animal proteins were tested for their ability to replace the expensive fishmeal with some cheap and alternate protein sources. Three experimental diets i.e A1, A2 and A3 were formulated with $40 \%$ crude protein using various ingredients like rice bran, wheat bran, mustard oil cake, silkworm pupae and Slaughter house waste and were fed to juveniles of Labeo rohita for a period of 60 days. In diet A1, fishmeal is the only protein source, in diet A2, fishmeal is replaced by silkworm pupae, in $\operatorname{diet} \mathrm{A} 3$, fishmeal is replaced by slaughter house waste. Result showed that the average weight gain, specific growth rate, percentage weight gain were lower in group fed with diet A2. However, no distinct variations were recorded between the treatments provided with diet A1 containing only fishmeal and diet A3 containing slaughter house waste. The results obtained recommended that slaughter house waste can replace the costly fishmeal up to $50 \% \mathrm{n}$ the diets of juveniles of Labeo rohita. Thus, the cost of production could be greatly reduced, thereby enhancing the economic returns.
\end{abstract}

Copy Right, IJAR, 2019,. All rights reserved.

\section{Introduction:-}

World population has increased and will likely to increase to nine billion, about $50 \%$ more food will be needed to sustain the quality of human life (by 2020). Terrestrial food resources have already been over utilized so we have to look forward for other equivalent food alternatives to meet the dietary demand of the geometrically growing population. To meet the dietary demand rich in all essential nutrients, aquaculture holds the potential to improve the livelihood of people living in developing countries and can deliver a wide range of benefits. Aquaculture is the cultivation of marine and fresh water species. Many species of marine and fresh water fish, crustaceans, mollusks and algae are cultivated in a variety of environment from ponds and rivers to open oceans. In fish farming, nutrition is critical because feed represents $40-50 \%$ of the production costs.

Feeds one of the major constraints for the expansion of aquaculture in terms of raw materials. Fish meal and fish oil have historically been the dominant raw materials in the production of fish feeds. Fish meal is very palatable and known for having high essential amino acid and fatty acid content and low levels of carbohydrates and anti nutritional factors (Zhou et al. 2004), moreover fish meal is highly digestible ensuring a high feed intake and nutrient utilization. Around 22 million tones of raw material s used of which $75 \%$ comes from whole fish and $25 \%$ from by- products of processing fish for human consumption (IFFO estimates). Across the globe, wild stock of 
small pelagic are straining under the pressure of wide spread commercial fishing activities and pollution hazards (MSG 2009; Zeller et al. 2011).

Globally aquaculture is expanding very fast and demand for fish meal and fish oil has doubled, therefore the aquaculture industry cannot continue to rely on finite stocks of small and large marine and fresh water pelagic fish as a supply of fishmeal and fish oil. This paradox of fishmeal and fish oil used in aquaculture has sparked major research into alternative feed ingredients to replace fishmeal and fish oil over the past two decades.

Efficient feed formulation should be made by utilizing equivalent alternate potential animal and protein sources. Animal protein sources are better option replace or minimize the use of fishmeal. Our present research attempts to evaluate growth performance of juveniles of Labeo rohita at various cost effective animal based resources.

\section{Material and methods \\ Experimental fish and acclimatization.}

Juveniles of Labeo rohita (Av. Wt 2.246 \pm 0.025) were brought from Gho-manasan fish farm in Jammu City and brought to laboratory in University of Jammu, where they were kept in plastic troughs of 20 L capacity. Fingerlings captured, were then acclimated in plastic troughs at a temperature of about $22-25^{\circ} \mathrm{C}$ for about 7 days and were fed on a mixture of rice bran and mustard oil cake

\section{Diet preparation.}

Three experimental diets were formulated with approximately equal amount of digestible $40 \%$ protein (predetermined) and digestible energy $(14.86 \mathrm{cl} / \mathrm{Kg})$. Various ingredients used were Fishmeal, soybean, rice bran, wheat bran, mustard oil cake, silkworm pupae, slaughter house waste and vitamin mineral mixture. Ingredients were thoroughly mixed and appropriate quantity of water was added and a dough was made. Dough was passed through a pelletizer and the pellets are dried at $37^{\circ} \mathrm{C}$ for two days. So, the concerned dried diet was packaged into plastic bag and stored until its usage.

\section{Experimental design.}

Juveniles of Labeo rohita at the beginning of experiment were stocked at a density of 25 in each plastic trough of 20 L capacity in triplicates. The experiment was conducted for 60 days. Initial weight and proximate composition of muscle of fish were determined prior to the commencement of the experiment. Juveniles of Labeo rohita were fed @ $5 \%$ of their body weight twice daily. The left over feed and excreta were removed on every second day by siphoning method separately from each tub. Before stocking, weight of the fingerlings were recorded.

\section{Measuring indices and methods.}

1. Weight gain $=$ Final weight $(\mathrm{g})-$ Initial weight $(\mathrm{g})$.

2. Specific growth rate $(\mathrm{SGR})=$ In final weight $(\mathrm{g})-\mathrm{In}$ initial weight $(\mathrm{g}) \times 100 /$ time (days).

3. Feed conversion ratio $=$ Diet fed $(\mathrm{g}) /$ total weight gain $(\mathrm{g})$.

4. Feed conversion efficiency $=[($ Gain in wet weight of fish $/$ feed fed $)] \times 100$.

\section{Biochemical Analysis.}

At the end of the experiment (after 60 days), juveniles were observed for weight increment followed by biochemical analysis. Proximate composition of the feed ingredients and experimental diets were determined in the laboratory using standard methods. The crude protein and lipid contents of feed ingredients were determined by Lowry method and Folch method. The ash content was determined by first igniting the sample and then heating it in the muffle furnace at $660^{\circ} \mathrm{C}\left( \pm 10^{\circ} \mathrm{C}\right)$ for $6 \mathrm{~h}(\mathrm{AOAC}, 1995)$.

\section{Statistical Analysis.}

Differences between treatments were analyzed using independent-measures one-way ANOVA. The values were expressed as mean \pm SE. values $p<0.05$ were considered as significant and $p$ values $<0.001$ were considered as highly significant $\mathrm{p}$.

Table 1:-Showing the composition of the three diets using different animal protein sources.

\begin{tabular}{|l|l|l|l|}
\hline Ingredients & Diet A1(SWP) & Diet A2(FM) & Diet A3(SHW) \\
\hline Rice bran & 12.00 & 13.00 & 20.00 \\
\hline Wheat bran & 16.00 & 15.00 & 14.00 \\
\hline Mustard oil cake & 20.00 & 20.00 & 15.00 \\
\hline
\end{tabular}




\begin{tabular}{|l|l|l|l|}
\hline Soybean & 17.00 & 15.00 & 20.00 \\
\hline Fishmeal & - & $\mathbf{3 6 . 0 0}$ & - \\
\hline Slaughter house waste & - & - & $\mathbf{3 0 . 0 0}$ \\
\hline Silkworm pupae & $\mathbf{3 4 . 0 0}$ & - & - \\
\hline vitamin \pm minerals & 1.00 & 1.00 & 1.00 \\
\hline
\end{tabular}

Table 2:-Showing the proximate composition of formulated diets using different animal protein sources.

\begin{tabular}{|l|l|l|l|}
\hline Parameters & Diet A1 & Diet A2 & Diet A3 \\
\hline Protein & 31.20 & 35.79 & 36.68 \\
\hline Lipid & 13.37 & 7.41 & 6.91 \\
\hline Moisture & 12.4 & 7.47 & 7.66 \\
\hline Ash & 7.52 & 18.94 & 12.33 \\
\hline
\end{tabular}

Table 3:-Initial Weight, Final Weight, Average weight, SGR, FCR, FCE and PWG.

\begin{tabular}{|l|l|l|l|}
\hline PARAMETERS & Diet A1 (SWP) & Diet A2 (FM) & Diet A3 (SHW) \\
\hline INITIAL WEIGHT & $2.246 \pm 0.025$ & $2.42 \pm 0.068$ & $2.416 \pm 0.020$ \\
\hline FINAL WEIGHT & $3.90 \pm 0.091$ & $4.376 \pm 0.070$ & $4.27 \pm 0.051$ \\
\hline $\begin{array}{l}\text { AVERAGE WEIGHT } \\
\text { GAIN }\end{array}$ & $1.48 \pm 0.080$ & $1.96 \pm 0.045$ & $1.85 \pm 0.035$ \\
\hline $\begin{array}{l}\text { SPECIFIC GROWTH } \\
\text { RATE }\end{array}$ & $2.13 \pm 0.772$ & $3.22 \pm 1.012$ & $2.70 \pm 0.831$ \\
\hline $\begin{array}{l}\text { FEED CONVERSON } \\
\text { RATIO (FCR) }\end{array}$ & $9.28 \pm 3.824$ & $6.55 \pm 2.499$ & $7.56 \pm 1.920$ \\
\hline $\begin{array}{l}\text { FEED CONVERSION } \\
\text { EFFICENCY (FCE) }\end{array}$ & $11.94 \pm 4.367$ & $16.66 \pm 5.714$ & $14.08 \pm 4.635$ \\
\hline $\begin{array}{l}\text { PERCENTAGE } \\
\text { WEIGHT GAIN (PWG) }\end{array}$ & $61.37 \pm 3.153$ & $81.40 \pm 3.361$ & $76.82 \pm 1.135$ \\
\hline
\end{tabular}

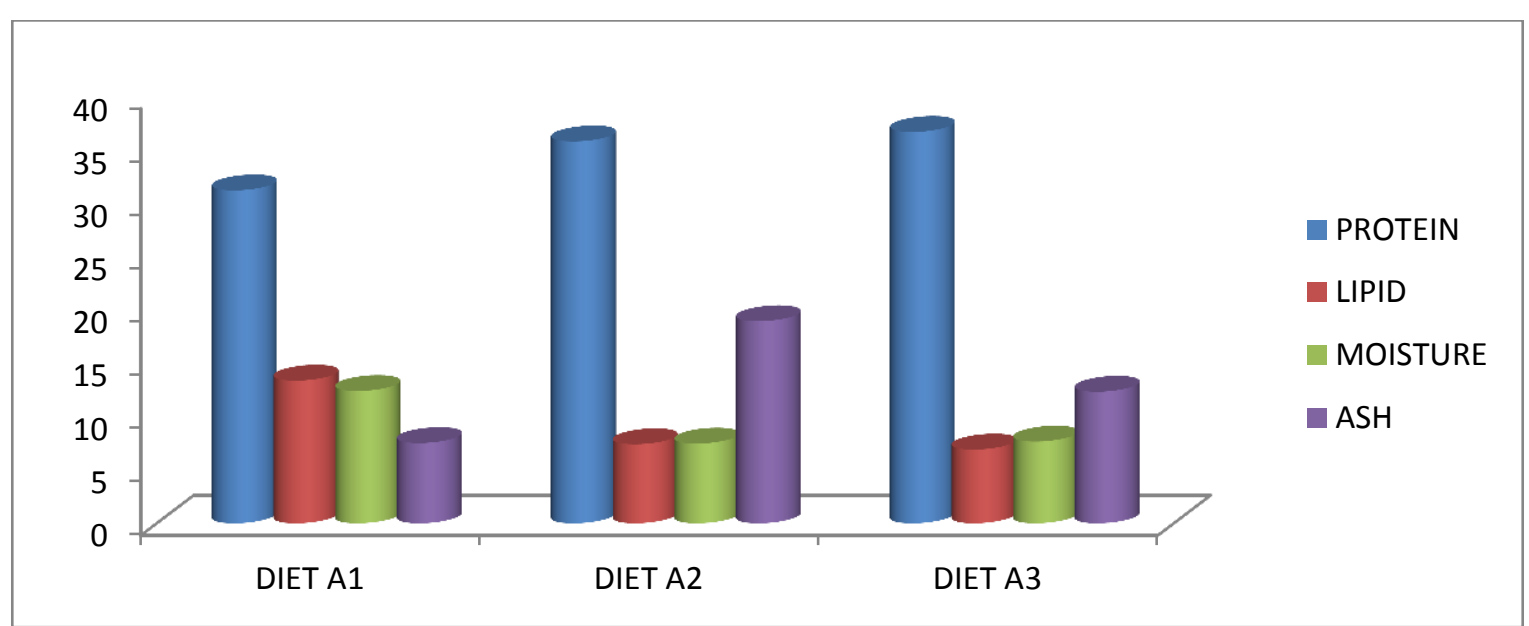

Fig 1:-Showing the proximate composition of diets formulated by using different animal protein sources. 


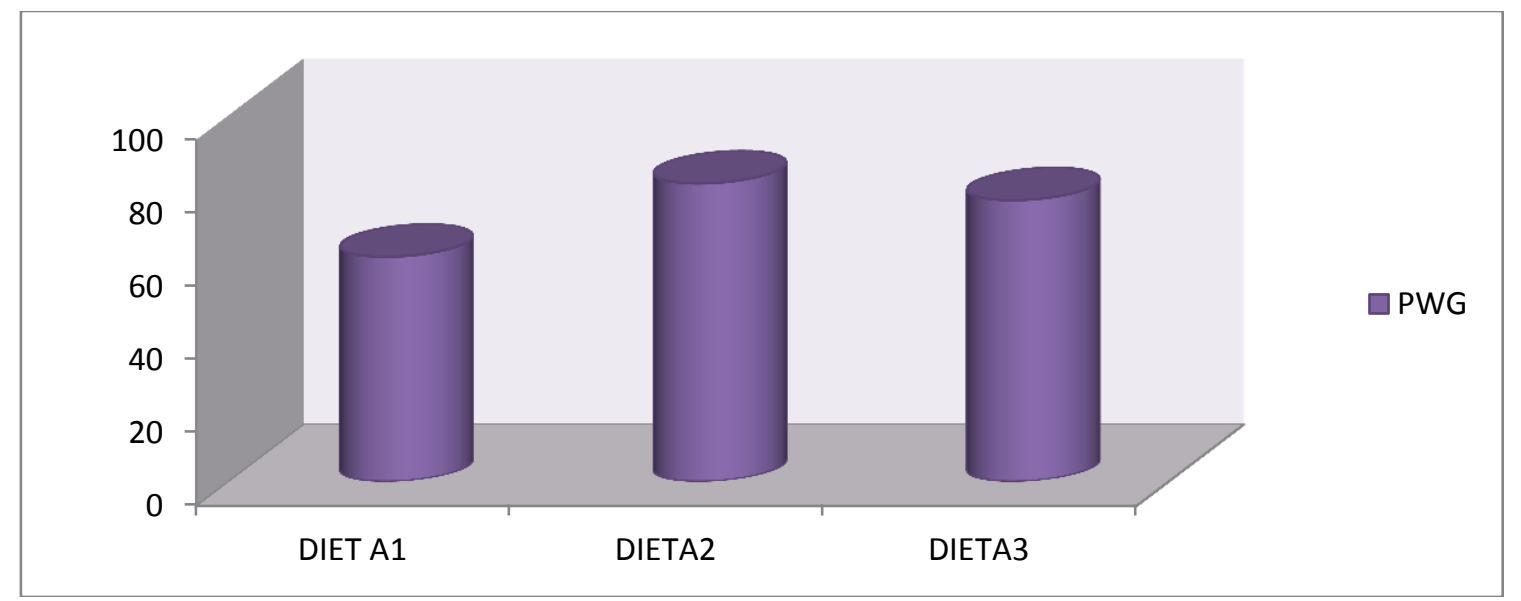

Fig 2:-Showing percentage weight gain (PWG) by juveniles of Labeo rohita fed on diets containng different animal protein sources.

\section{Results and discussions:- \\ Growth studies}

Perusal of table 3 and fig 2 shows data on the weight increment of Labeo rohita (average weight 2.42 \pm 0.025 ) after every fifteen days. The mean growth of juveniles of Labeo rohita when fed on diet A2 and A3 was $4.37 \pm 0.070$ and $4.27 \pm 0.051$ respectively in comparison to $3.90 \pm 0.091$ in diet A1. This show significant difference in growth rates between Diet A1 and Diet A2 and diet A1 and diet A3. However the value did not show any significant variation between the treatment group fed on fishmeal and slaughter house waste diet. This shows the possibility of substitution of fishmeal with slaughter house waste meal in the fish feed formulation. Similar observations have been found by J K Jena et al (1998), other sources of animal protein has been found to have encouraging results. Silkworm pupae has been found as good and less expensive alternative source of protein in fish diet formulation. Slaughter house waste such as blood, condemned offal and condemned carcasses can be used for blood meal and bone meal which find use for fish diet formulation (Biswas 2003).

Fermented fish Offal is also viable alternative fish meal in the formulation of diets for fishes (Mondal et al., 2012). Tabinda and Butt (2012) reported compromising growth and feed conversion ratio when by replacing fishmeal with 75\% chicken intestine meal. Keremah (2013) showed that crab meal diet show appreciable performance and could have potential use as a partial replacer of FM at a particular level.

Tabinda et al (2013) reported that $100 \%$ chicken intestine could be substituted for fish meal without addition of fishmeal in Cirrhinus mrigala fingerlings. Ji et al. (2013) demonstrated that it is practical to replace 50\% of the jian carp (Cyprinus carpio jian) fishmeal protein with silkworm pupae. Natesan et al. (2014). Demonstrated that spirulina meal is a potential protein substitute of fishmeal in shrimp diet.

\section{Specific growth rate}

A perusal of table 3, revealed higher specific growth rate in diet A2 i.e 3.22 \pm 1.012 and A3 i.e 2.70 \pm 0.831 as against $\operatorname{diet}$ A1 with 2.13 \pm 0.772 , no significant differences was observed between diet A2 and diet A3. Mohanty et al., (1996) perform experiments with rohu spawn fed with four liver based diets also recorded comparatively low SGR values while raised under laboratory conditions.

\section{Protein efficiency ratio}

The value of PER was recorded to be highest for diet A3 i.e $0.854 \pm 0.740$, followed by 0.491 with diet A1 and $0.469 \pm 0.159$ for diet A2 (table 3)

\section{Percentage weight gain}

Data from table 3 and fig. 2 shows that at the end of experiment after 60 days, the total percentage weight gain by juveniles of during the course of experiment were calculated, the maximum percentage of weight gain was shown by $\operatorname{diet} \mathrm{A} 2(81.40 \pm 3.361)$ followed by diet A3 (76.82 \pm 1.134$)$ and minimum in diet A1 (61.37 \pm 3.153$)$. 


\section{Conclusion:-}

Results of the present study reveal marked differences in growth, SGR and PER values between the three test groups, showing the essential requirement of the animal protein source in the supplementary diet possibly to supplement the much needed essential amino acids and fatty acids. However, no distinct variation in the aforesaid aspects were observed between the treatments provided with diets containing fishmeal and slaughter house waste meal as the source of animal protein, thereby confirming the possibility of incorporation of slaughter house waste as a substitute for fishmeal in the carp diet formulation.

\section{Bibliography:-}

1. AOAC (1995). Official Methods of Analysis. 16th Edn., Association of Official Analytical Chemists, Washington, DC., USA.

2. Biswas, G. (2003). Slaughter house waste utilization. Newsletter, EMCB-ENVIS node on environmental biotechnology, Department of Environmental Science, University of Kalyani, Vol 3, 3-4.

3. Folch, J., Lees, M. and Stanley, G.H.S. (1957). A simple method for the isolation and purification of total lipids from animal tissue. Journal of Biological Chemistry, 226: 497-509

4. Jena, J.K., Mukhopadhyay, P.k. and Aravindakshan,P.K. (1998). Dietary incorporation of meat meal as a substitute for fish meal in carp fry rearing. Indian J.Fish; 45(1):43-49.

5. Jena, J.K., Mukhopadhyay, P.k. and Aravindakshan,P.K. (1998). Dietary incorporation of meat meal as a substitute for fish meal in carp fry rearing. Indian J.Fish; 45(1):43-49.

6. Lowry, O. H., Rosenbrough, N. J., Farr, A. L. and Randall, R. J. (1951). Protein measurement with the folin phenol reagent. J. Biol. Chem., 193: 265-275.

7. Natesan, S., Muthuraman, S. and Gopal, S. (2014). Efficacy of dietary supplementation of cyanobacterial meal on growth performance of Black tiger shrimp Penaeus monodon (Fabricus). Cibtech journal of zoology. 3(1): 61-69.

8. Mohanty, S. N., Swamy, D. N. and Tripathy, S. D. (1990). Protein utilization in indian Major carp fry, Catla catla (Ham.) and Labeo rohita (Ham.) fed four protein. J.Aqua. Trop. 5: 173-179.

9. Tabinda, A.B and Butt, A. (2012). Replacement of Fish Meal With poultry by-product meal (chicken intestine) as a protein source in grass carp fry diet. Pakistan J. Zool., 44(5): 1373-1381.

10. Tabinda, A. B., Ghazala, R., Yasar, A. and Ashraf, M. (2013). Utilization of chicken intestine as an alternative protein sources in the diet for fingerlings of Cirrhinus mrigala. The journal of animal and plant sciences, 23(6): 1603-1608.

11. Keremah, R.I. (2013). The effects of replacement of fishmeal with crab meal on growth and feed utilization of African gaint catfish Heterobranchus longifilis fingerlings. International journal of fisheries and aquaculture 5(4): 60-65.

12. Zhou, Q., Tan, B., Sen Mai, K. and Lu, Y. (2004). Apparent digestibility of selected feed ingredients for juveniles cobia (Rachycentron canadum). Aquaculture.241:441-451.

13. Zeller, D., Rossng, P., Harper, S., Persson, L., Booth, S. and Pauly, D. (2011). The Baltic Sea: Estimates of total fisheries removal 1950-2007. Fisheries Research. 108 (2-3): 356-363. 